\title{
Chemically modified tetranitro-oxacalix[4]arenes: synthesis and conformational preferences of tetra- $N$-(1-octyl)ureido-oxacalix[4]arenes
}

\author{
Calogero Capici, ${ }^{a}$ Domenico Garozzo, ${ }^{b}$ Giuseppe Gattuso, ${ }^{a}$ Angela Messina, ${ }^{b}$ Anna Notti, ${ }^{a}$ \\ Melchiorre F. Parisi, ${ }^{a}{ }^{*}$ Ilenia Pisagatti ${ }^{a}$ and Sebastiano Pappalardo ${ }^{c}$ \\ ${ }^{a}$ Dipartimento di Chimica Organica e Biologica, Università di Messina, Salita Sperone 31, \\ 98166 Messina, Italy; ${ }^{b}$ CNR, ICTP Catania, Via Gaifami 18, 95126, Italy; ${ }^{c}$ Dipartimento di \\ Scienze Chimiche, Università di Catania, Viale A. Doria 6, 95125 Catania, Italy \\ E-mail: mparisi@unime.it
}

In honor of Professor Nicolò Vivona on the occasion of his $70^{\text {th }}$ birthday

\begin{abstract}
Tetranitro-oxacalix[4]arenes 1-5, prepared by direct $\mathrm{S}_{N} \mathrm{Ar}$ reaction of 1,5-difluoro-2,4dinitrobenzene with the appropriate aromatic diol (pyrocatechol, resorcinol, hydroquinone, 2,7dihydroxynaphthalene, and 4,4'-dihydroxybiphenyl), were subjected to Raney-nickel reduction to provide the corresponding tetraamino-oxacalix[4]arenes 6-10, which upon treatment with an excess of 1-octyl isocyanate were converted into the title compounds 11-15, featuring a pair of 1,3-bis-[ $N$-(1-octyl)ureido]phenylene moieties doubly connected at their 4,6-positions by rigid spacers of varied geometry. All new oxacalix[4]arenes were characterized by MALDI-TOF spectrometry and NMR spectroscopy. ${ }^{1} \mathrm{H}$ NMR data and ab initio calculations support saddleshaped conformations for oxacalix[4]arenes incorporating pyrocatechol, resorcinol and 2,7dihydroxynaphthalene nucleophilic components, and boat-shaped conformations for derivatives possessing hydroquinone and 4,4'-dihydroxybiphenyl spacers.
\end{abstract}

Keywords: Ab initio calculations, anion receptors, calixarenes, heterocalixarenes, macrocycles, nitro group reduction, ureido ligands

\section{Introduction}

The three-dimensional architecture of calixarenes, their easy preparation and functionalization, tunable size, unique conformational properties and versatile molecular recognition abilities, have established this class of compounds as one of the prime building blocks in host-guest and supramolecular chemistry. ${ }^{1}$ Furthermore, the incorporation of bridging atoms other than carbon 
within their framework provides a means to expand calixarene structural diversity, producing new-generation macrocyclic host molecules with unexplored chemical and physical properties. As a matter of fact, in the past few years heteroatom-bridged calix(hetero)arenes have received special attention as new potential scaffolds for the design of supramolecular structures. ${ }^{2}$

Oxygen-bridged calixarenes, henceforth referred to as oxacalixarenes, can be viewed as rigid crown ethers built up with fully aromatic rings only. ${ }^{3}$ The meta-bridged ( $\left.m-, m-, m-, m-\right)$ 16membered tetranitro-oxacalix[4]arene 2 was first synthesized in modest yield in 1966 by direct nucleophilic aromatic substitution $\left(\mathrm{S}_{\mathrm{N}} \mathrm{Ar}\right)$ of resorcinol with 1,5-dichloro-2,4-dinitrobenzene. ${ }^{4}$ Subsequently, papers in the mid-seventies extended this procedure to the preparation of isomeric 14- and 18-membered macrocycles with an alternating ( $\left.m-, o^{-}, m_{-}^{-}, o^{-}\right)$and $(m-, p-, m-, p-)$ bridging sequence, best exemplified by the parent compounds $\mathbf{1}$ and $\mathbf{3}$, by using pyrocatechol and hydroquinones as the nucleophilic components, respectively. ${ }^{5,6}$ Then, for almost three decades, only sporadic studies were conducted on related compounds, ${ }^{7,8}$ probably due to the limited solubility of earlier materials, which hampered their purification and characterization. ${ }^{9}$

Quite recently, Katz et al. achieved an important breakthrough in oxacalix[4]arene chemistry when they found that various tetranitro-oxacalix[4]arenes can be generated in excellent yield by the room temperature $\mathrm{S}_{\mathrm{N}} \mathrm{Ar}$ reaction of resorcinols (nucleophilic components) with 1,5-difluoro2,4-dinitrobenzene (electrophilic component) in dimethylsulfoxide (DMSO) under basic conditions. ${ }^{10}$ The excellent yields of the cyclic tetramer over potentially accessible larger structures can be attributed to thermodynamic product control under equilibrating conditions. ${ }^{11}$ The reaction did not require high dilution conditions, and tolerated a wide range of substituents (alkyl, formyl, ester, hydroxyl, and even porphyrin ${ }^{12}$ ) on the nucleophilic component, chosen either to impart better solubility characteristics to the macrocycles, or to pursue specific structural modifications by further derivatization. ${ }^{13}$ The use of dihalo- $N$-heterocycles as the electrophilic component in the $S_{N} A r$ reactions with aromatic diols, has expanded calixarene structural diversity to include oxacalix[2]arene[2]pyridines, ${ }^{14}$-[2]pyrazines, ${ }^{14 c}$ -[2]pyrimidines, ${ }^{14 c, 15}$-[2]triazines, ${ }^{16}$ and oxacalix[2]naphthalene[2]naphthyridines as well. ${ }^{17}$

Although tetranitro-oxacalix[4]arenes are ideal precursors of more sophisticated aminocontaining molecular architectures, the chemical alteration of the nitro functions in such compounds has lagged behind, probably as a consequence of their scarce solubility. ${ }^{18}$ In this paper we report the preparation of a series of tetranitro-oxacalix[4]arenes 1-5, their successful reduction to the corresponding tetraamino derivatives $\mathbf{6}-\mathbf{1 0}$, and smooth conversion into tetra- $N$ (1-octyl)ureido-oxacalix[4]arenes 11-15. The conformational preferences of all oxacalix[4]arenes synthesized have been deduced with the aid of ${ }^{1} \mathrm{H}$ NMR spectroscopy and calculations of equilibrium geometries. The title compounds show the potential to act as neutral hydrogen-bonding anion receptors in polar media. ${ }^{19}$

\section{Results and Discussion}


The synthetic sequence to oxacalix[4]arenes 1-15 described in this paper and relevant ringsystem numbering schemes are shown in Scheme 1. The starting tetranitro-oxacalix[4]arenes 1-5 were obtained in $58-82 \%$ yield by direct nucleophilic aromatic substitution $\left(\mathrm{S}_{\mathrm{N}} \mathrm{Ar}\right)$ of $1,5-$ difluoro-2,4-dinitrobenzene with the appropriate aromatic diol (pyrocatechol, resorcinol, hydroquinone, 2,7-dihydroxynaphthalene, or 4,4'-dihydroxybiphenyl) in refluxing $N, N$ dimethylformamide (DMF) in the presence of triethylamine (TEA).
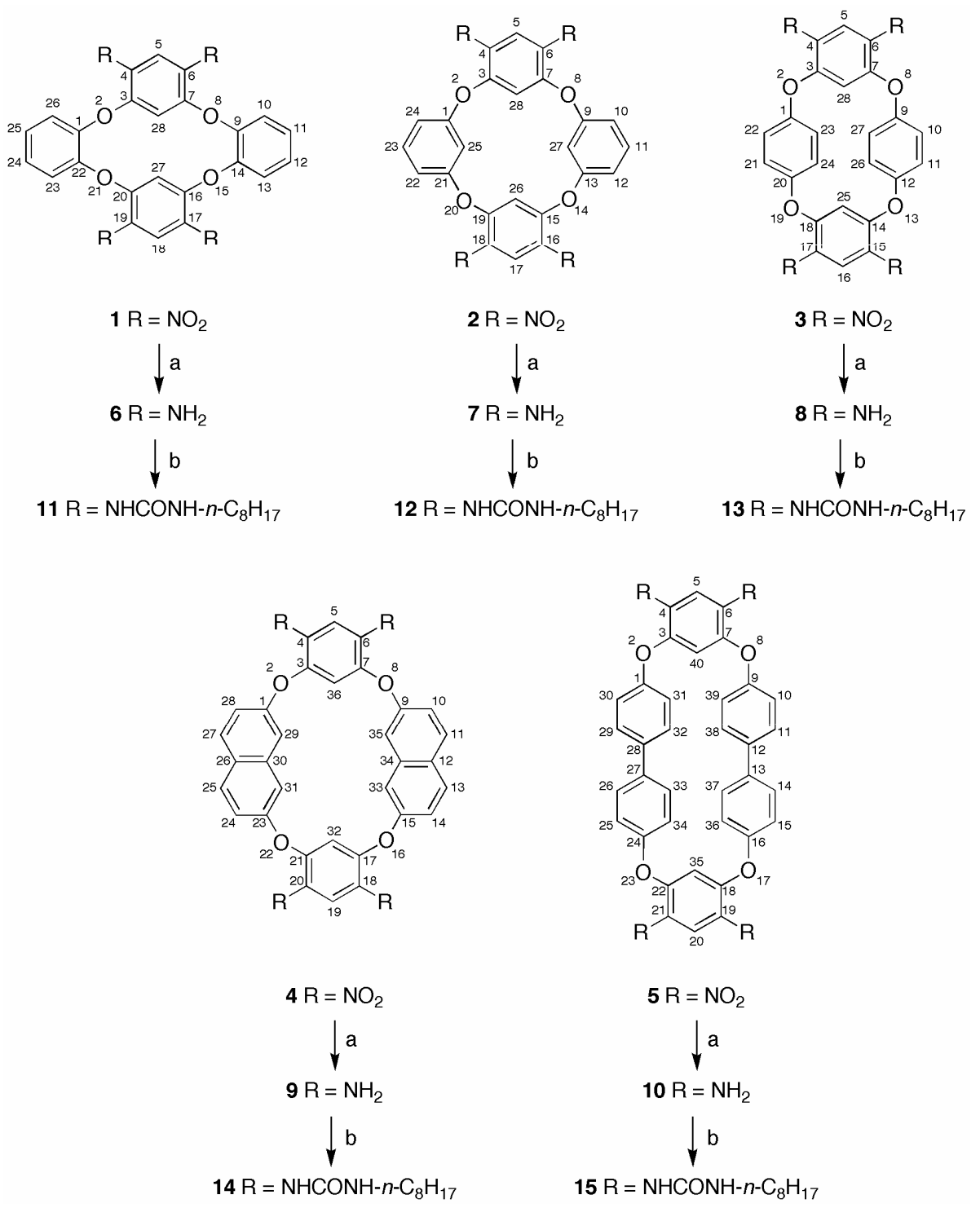

Scheme 1. Synthesis of tetraureido-oxacalix[4]arenes 11-15 starting from tetranitro-derivatives 1-5. Reagents: (a) $\mathrm{H}_{2}$, Raney-nickel, THF or DMF; (b) $\mathrm{CH}_{3}\left(\mathrm{CH}_{2}\right)_{7} \mathrm{NCO}, \mathrm{CHCl}_{3}$ or DMSO. See Experimental Section for details. 
The cyclic tetramers, precipitating out from the cooled reaction mixtures, after thorough washing with methanol were pure enough for the subsequent step. By following a synthetic protocol previously used for the preparation of (bis)ureido-calix[5]arenes, ${ }^{20}$ when a slurry of tetranitro-oxacalix[4]arene in freshly distilled tetrahydrofuran (THF, compds 1, 2, 4 and 5) or $N, N$-dimethylformamide (DMF, compd 3) was subjected to $\mathrm{H}_{2}$ (1 atm) in the presence of Raneynickel, the corresponding tetraamino-oxacalix[4]arenes were obtained (76-86\% yield for 6, 7 and 9, respectively). Tetraamino derivatives $\mathbf{8}$ and 10, derived from hydroquinone and 4,4'dihydroxybiphenyl nucleophilic components, were not isolated. Their formation was demonstrated by ${ }^{1} \mathrm{H}$ NMR but, owing to their very low solubility in most common organic solvents (vide infra), they were used without further purification in the following step after removal of the nickel catalyst. Progress of the reaction was conveniently monitored by ${ }^{1} \mathrm{H} \mathrm{NMR}$ spectroscopy in DMSO- $d_{6}$, by following the disappearance of the low-field resonance of the aromatic proton between the two nitro groups of the electrophilic component moiety $(\delta=8.70$ $9.05 \mathrm{ppm})$, and the appearance of a high-field resonance for the newly formed amino groups ( $\delta=4.05-4.63 \mathrm{ppm})$. Subsequent conversion of amino compounds 6-10 into tetra- $N$-(1octyl)ureido-oxacalix[4]arenes 11-15 was achieved by treatment with an excess of 1-octyl isocyanate in dry DMSO (for 11 and 13-15) or $\mathrm{CHCl}_{3}$ (for 12). Ureido-oxacalix[4]arenes 11, 12, and 14 were isolated in 22, 37 and 23\% yield, respectively, whereas 13 and 15 were obtained in 26 and 36\% yield (calculated over two steps from the corresponding tetranitro precursors 3 and 5). Completion of the reaction is signaled by the total disappearance of the broad amino resonance, which is in turn replaced by a lower field $\left(\mathrm{D}_{2} \mathrm{O}\right.$ exchangeable) singlet-triplet pattern for the newly formed $\mathrm{NHC}(\mathrm{O}) \mathrm{NHC}_{8} \mathrm{H}_{17}$ groups. In general, oxacalix[4]arenes 1-15 show limited solubility in high-boiling polar solvents (DMF, DMSO, ortho-dichlorobenzene, nitrobenzene, hexamethyl phosphoramide, etc.) at room temperature.

The ${ }^{1} \mathrm{H}$ NMR spectra of the oxacalix[4]arenes 1-15 are characterized by high field resonances for the intra-annular aromatic protons of the electrophilic component $(\delta=5.12-6.72$ ppm, see Figure 1 for 11-15), owing to the diamagnetic shielding arising from the flanking aromatic rings, which is a function of the molecular conformation. ${ }^{5,9,21}$ This suggests that tetranitro-oxacalix[4]arene precursors 1,2 and $\mathbf{4}$ and their amino $(\mathbf{6}, \mathbf{7}, \mathbf{9})$ and ureido $(\mathbf{1 1}, \mathbf{1 2}, \mathbf{1 4})$ derivatives (see Scheme 1) preferentially adopt a saddle-shaped (1,3-alternate) conformation in solution. This particular conformation is presumably enforced by the tendency to maintain conjugation between the bridging oxygen atoms and the originally electron-poor (nitro-bearing) aromatic rings. This conclusion, based on ${ }^{1} \mathrm{H}$ NMR data, is in good agreement with the results of a series of X-ray diffraction studies on related oxacalix[4](hetero)arenes. The structural data have shown that the aromatic rings of the electrophilic component approach coplanarity; while the rings of the nucleophilic component are eclipsing and nearly parallel. ${ }^{10,16,17}$ On the other hand, although the intra-annular protons of the electrophilic component in tetranitrooxacalix[4]arenes 3 and 5 and their amino $(\mathbf{8}, \mathbf{1 0})$ and ureido $(\mathbf{1 3}, \mathbf{1 5})$ derivatives resonate at the usual high field strengths $(\delta=5.12-6.23 \mathrm{ppm}){ }^{22}$ the geometric features of their nucleophilic components impart to these molecules equally plausible boat or chair conformations. 


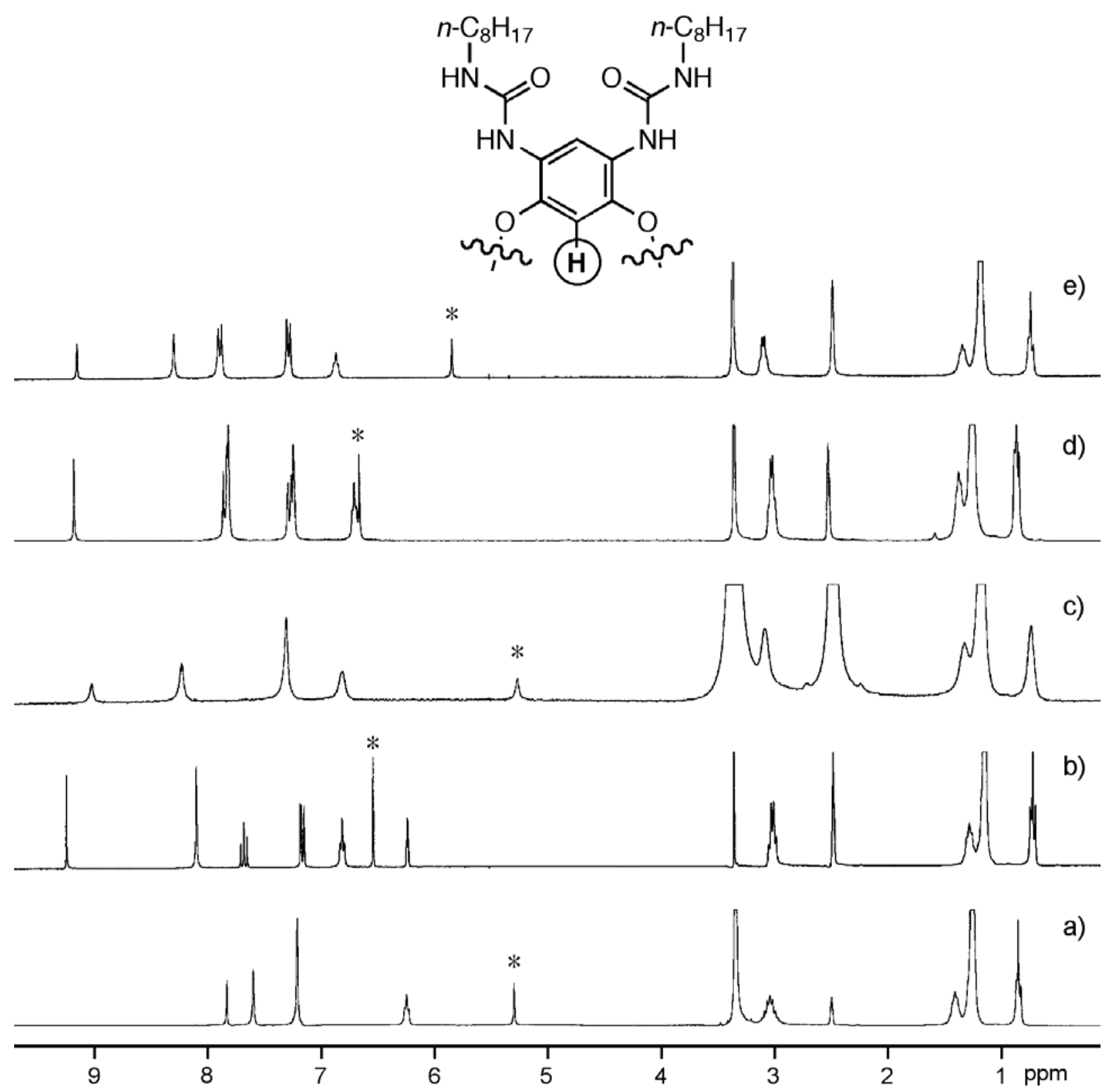

Figure 1. ${ }^{1} \mathrm{H}$ NMR spectra (300 MHz, DMSO- $\left.d_{6}, 22{ }^{\circ} \mathrm{C}\right)$ of tetra- $N$-(1-octyl)ureidooxacalix[4]arenes 11-15 (traces $a$ to $e$, respectively). The asterisks indicate the peaks for the intra-annular hydrogen atoms.

In order to gain an insight into the overall geometry of ureido-oxacalix[4]arenes 11-15, so as to evaluate optimal geometrical fitting of putative (poly)anion guests for cooperative binding to the facing ureido functions, in the absence of single crystals suitable for an X-ray analysis, $a b$ initio calculations were performed by using the Hartree-Fock method with the 6-31G* basis set. $^{23}$ To decrease the degrees of freedom, and simplify the calculations, the $n$-octyl moieties were replaced by methyl groups (compds Me-11-Me-15, Figure 2). 


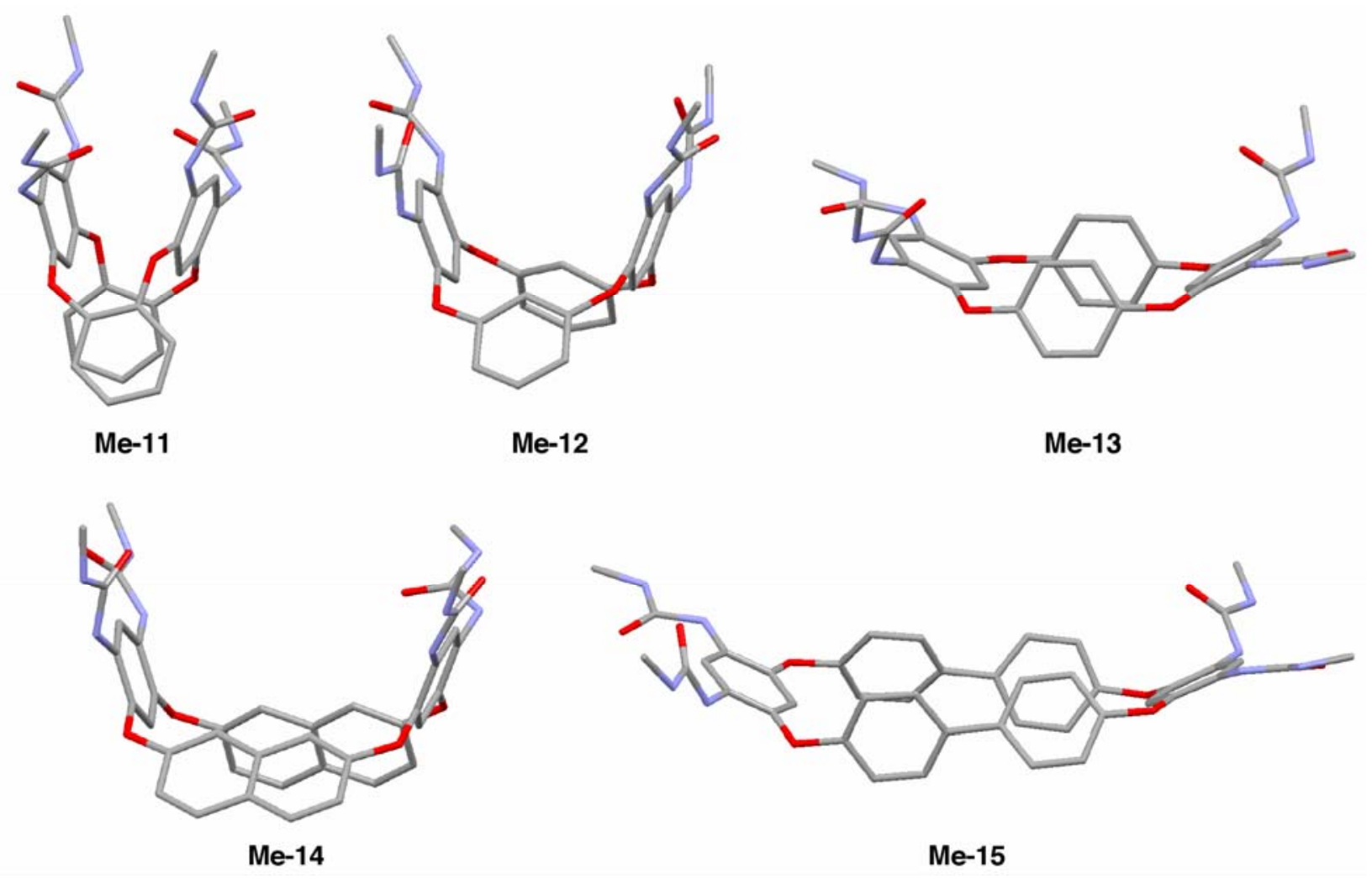

Figure 2. Optimized ground-state geometries for model compounds Me-11-Me-15 (derived from ureido-oxacalix[4]arenes $\mathbf{1 1 - 1 5}$ by replacement of the $n$-octyl moieties with methyl groups), obtained by HF/6-31G* ab initio calculations. Hydrogen atoms omitted for clarity.

The first interesting observation was that all the structures calculated adopt a boat-like conformation, featuring the ureido-bearing aryl groups in a syn relationship with respect to the mean plane generated by the four bridging oxygen atoms. Ureido-oxacalix[4]arenes $\mathbf{M e - 1 3}$ and Me-15 share great similarities. The ureido-bearing aryl groups lie in a wide-open and slightly twisted arrangement, the angles between the rings mean planes being $124.9^{\circ}$ and $124.2^{\circ}$, respectively. The distances between the centroids of these rings vary considerably (7.87 and $12.12 \AA$, respectively) according to the length of the spacer. Compounds Me-11, Me-12 and Me14 on the other hand, present with the ureido-aryl rings facing each other in a slightly divergent arrangement. The angles formed by the mean planes of these aryl rings are in the $30-40^{\circ}$ range (Table 1), while the distances between their centroids are 3.78, 5.60 and $8.12 \AA$, respectively. The structural features of the latter model compounds indicate that tetraureido-oxacalix[4]arenes $\mathbf{1 1}, \mathbf{1 2}$, and $\mathbf{1 4}$ are the best candidates for an initial screening of the anion-complexation abilities. Indeed, it is likely that as a result of the relatively small angle formed by the aryl groups, the ureido moieties may have the correct geometry to act cooperatively for a tweezers-type complexation of suitably-sized anions. 
The calculated geometries of the ureido-oxacalix[4]arenes Me-11-Me-15 are additionally substantiated by careful analysis of the ${ }^{1} \mathrm{H}$ NMR spectra of their parent compounds (Figure 1). The chemical shift observed for the intra-annular hydrogen atoms of compounds 12 and 14 (H26/28 and H-32/36, respectively) are in good agreement with their calculated spatial arrangement (Figure 1, traces $b$ and $d$, respectively). Inspection of the molecular models Me-12 and Me-14 suggests that, because of the angle imposed by the resorcinol and 2,7-dihydroxynaphthalene spacers, the pertinent intra-annular hydrogen atoms can not enjoy the shielding of the nearby aromatic spacers and as a result resonate at modestly high fields ( $\delta=6.32-6.62 \mathrm{ppm}$ ). Conversely, the analogous intra-annular hydrogen atoms for 11, 13 and 15 reside closer to the shielding cones of their spacers, and therefore resonate at much higher fields $(\delta=5.12-$ $5.66 \mathrm{ppm}$ ) with respect to 12 and $\mathbf{1 4}$ (Figure 1, traces $a, c$, and $e$, respectively).

Table 1. Centroid-centroid distances and interplanar angles formed by the aryl moieties bearing the ureido groups for model compounds Me-11-Me-15.

\begin{tabular}{llllll}
\hline & Me-11 & Me-12 & Me-13 & Me-14 & Me-15 \\
\hline centroid distance $(\AA)$ & 3.78 & 5.60 & 7.87 & 8.12 & 12.12 \\
mean planes angle $\left(^{\circ}\right)$ & 29.6 & 37.3 & 124.9 & 40.2 & 124.2 \\
\hline
\end{tabular}

\section{Conclusions}

A new family of oxacalix[4]arenes endowed with extra-annular ureido functionalities was synthesized, by applying methodologies which had previously proved successful for classical calix $[n]$ arenes. Their structures and conformations were established by a combination of MALDI-TOF spectrometry, NMR investigations and computational methods. The results obtained from the $a b$ initio calculations were found to be in excellent agreement with the spectroscopic data presented. Future studies will be directed to the evaluation of the anion binding abilities of the tetra- $N$-(1-octyl)ureido-oxacalix[4]arenes towards mono- and polyanions, and to the design and synthesis of new tetraureido-oxacalix[4]arene derivatives with improved solubility in organic solvents and water.

\section{Experimental Section}

General Procedures. Melting points were determined on a Kofler hot stage apparatus and are uncorrected. Unless otherwise stated, ${ }^{1} \mathrm{H}$ and ${ }^{13} \mathrm{C}$ NMR spectra were recorded at room temperature in DMSO-d6 at 300 and $75 \mathrm{MHz}$, respectively. ${ }^{13} \mathrm{CNMR}$ spectra of compds $\mathbf{3}, \mathbf{5}$ and 8 could not be recorded because of very poor solubility of the samples. THF and $\mathrm{CHCl}_{3}$ were dried by standard methods ${ }^{24}$ prior to use; other chemicals were reagent grade and were used without further purification. MALDI-TOF mass spectra were performed using a Voyager STR 
instrument (Applied Biosystems, Framingham, MA) equipped with a nitrogen laser $(\lambda=337 \mathrm{~nm})$ and delayed extraction technology. Ions generated by the pulsed laser beam were accelerated through a $24 \mathrm{kV}$ electric field. Mass spectra are the result of 256 laser shots. High resolution positive-ion mass spectra were acquired in reflector mode. External mass calibration was performed, and mass accuracy was better than $20 \mathrm{ppm}$. Briefly, $0.5 \mu \mathrm{L}$ of each sample, dissolved in DMSO, was deposited onto a stainless-steel MALDI sample plate, with the same volume of matrix solution and left to dry at room temperature for two days. Among the three different matrix solutions tested ( $\alpha$-cyano-4-hydroxycinnamic acid, 2-(4-hydroxyphenylazo)-benzoic acid, and 5-chloro-2-mercaptobenzothiazol), the best results were obtained with $\alpha$-cyano-4hydroxycinnamic acid $\left(10 \mathrm{mg} / \mathrm{mL}\right.$ in $\left.\mathrm{CH}_{3} \mathrm{OH}\right)$. All attempts to get MALDI-TOF mass spectra of compds 4, 5, 8 and 10 under the experimental conditions used were unsuccessful. Elemental analyses were carried out by Redox s.n.c. (Monza, Italy).

General procedure for the synthesis of tetranitro-oxacalix[4]arenes 1-5. A slight modification of Lehmann's procedure ${ }^{5}$ was used. A stirred solution of 1,5-difluoro-2,4dinitrobenzene (204 mg, $1 \mathrm{mmol}$ ), the appropriate diol (1 equiv.), and TEA (0.3 mL, 2.2 equiv.) in dry DMF (10 mL) was refluxed for 0.5-2 h. After cooling, the precipitate was collected by filtration, and thoroughly washed with methanol to leave a pale yellow powder, which analyzed correctly for the desired macrocycle.

4,6,17,19-Tetranitro-2,8,15,21-tetraoxacalix[4]arene (1). $156 \mathrm{mg}, 57 \%$ yield; $\mathrm{Mp}>350{ }^{\circ} \mathrm{C}$ (lit. ${ }^{5}$, M.p. $>350{ }^{\circ} \mathrm{C}$ ); ${ }^{1} \mathrm{H}$ NMR $\delta 5.68$ (s, $2 \mathrm{H}, 27,28-\mathrm{ArH}$ ), 7.44-7.60 (AA'BB', $8 \mathrm{H}$, $10,11,12,13,23,24,25,26-\mathrm{Ar} H$ ), 8.70 (s, $2 \mathrm{H}, 5,18-\mathrm{ArH}$ ) ppm; ${ }^{13} \mathrm{C}$ NMR $\delta 106.2,125.4,125.7$, 129.2, 131.9, 143.2, $153.2 \mathrm{ppm}$.

4,6,16,18-Tetranitro-2,8,14,20-tetraoxacalix[4]arene (2). $200 \mathrm{mg}, 73 \%$ yield; M.p. > $350{ }^{\circ} \mathrm{C}$ (lit. ${ }^{4,5,9}, \mathrm{Mp}>350{ }^{\circ} \mathrm{C}$ ); ${ }^{1} \mathrm{H}$ NMR $\delta 6.72$ (s, $2 \mathrm{H}, 26,28-\mathrm{ArH}$ ), 7.19 (dd, $J=2.0,8.2 \mathrm{~Hz}, 4 \mathrm{H}$, 10,12,22,24-ArH), 7.21 (t, $J=2.0 \mathrm{~Hz}, 2 \mathrm{H}, 25,27-A r H), 7.57$ (td, $J=1.5,8.2 \mathrm{~Hz}, 2 \mathrm{H}, 11$,23$\mathrm{ArH}$ ), 8.93 (s, $2 \mathrm{H}, 5,17-\mathrm{Ar} H$ ) ppm; ${ }^{13} \mathrm{C}$ NMR $\delta 108.9$, 110.5, 117.9, 124.8, 132.6, 134.2, 154.5, $155.1 \mathrm{ppm}$.

4,6,15,17-Tetranitro-2,8,13,19-tetraoxacalix[4]arene (3). $165 \mathrm{mg}, 60 \%$ yield; $\mathrm{Mp}>350{ }^{\circ} \mathrm{C}$ (lit. ${ }^{5,6}$, Mp > $350{ }^{\circ} \mathrm{C}$ ); ${ }^{1} \mathrm{H}$ NMR $\delta 7.44,7.56,8.94$ (s, 4:1:1, $12 \mathrm{H}, 10,11,21,22,23,24,26,27-\mathrm{ArH}$, 25,28-ArH, and 5,16-ArH, respectively) ppm.

4,6,18,20-Tetranitro-2,8,16,22-tetraoxacalix[2]arene[2]naphthalene (4). $267 \mathrm{mg}$, 82\% yield; M.p. 347-350 ${ }^{\circ} \mathrm{C}$ (dec); ${ }^{1} \mathrm{H}$ NMR $\delta 6.59$ (s, $2 \mathrm{H}, 32,36-\mathrm{ArH}$ ), 7.35 (dd, $J=2.4,8.9 \mathrm{~Hz}, 4 \mathrm{H}$, 10,14,24,28-naphth), 7,60 (d, $J=2.4 \mathrm{~Hz}, 4 \mathrm{H}, 29,31,33,35-$ naphth), 7.98 (d, $J=8.9 \mathrm{~Hz}, 4 \mathrm{H}$, 11,13,25,27-naphth), 9.05 (s, 2 H, 5,19-ArH) ppm; ${ }^{13} \mathrm{C}$ NMR (125 MHz) $\delta 110.3,114.4,119.6$, 125.2, 128.2, 130.9, 134.2, 134.5, 152.9, 154.5 ppm. Anal. Calcd. for $\mathrm{C}_{32} \mathrm{H}_{16} \mathrm{~N}_{4} \mathrm{O}_{12}$ : C 59.27; $\mathrm{H}$ 2.49; N 8.64. Found: C 58.98; H 2.60; N 8.69.

4,6,19,21-Tetranitro-2,8,17,23-tetraoxacalix[2]arene[2]biphenyl (5). $280 \mathrm{mg}, 80 \%$ yield; M.p. $>350{ }^{\circ} \mathrm{C}$; ${ }^{1} \mathrm{H}$ NMR $\delta 5.87$ (s, $\left.2 \mathrm{H}, 35,40-\mathrm{ArH}\right), 7.24$ and $7.70(\mathrm{ABq}, J=8.6 \mathrm{~Hz}, 16 \mathrm{H}$, 
10,11,14,15,25,26,29,30,31,32,33,34,36,37,38,39-biph), 8.97 (s, 2 H, 5,20-ArH) ppm. Anal. Calcd. for $\mathrm{C}_{36} \mathrm{H}_{20} \mathrm{~N}_{4} \mathrm{O}_{12}$ : C 61.72; H 2.88; N 8.00. Found: C 61.43; H 2.97; N 8.07.

4,6,17,19-Tetraamino-2,8,15,21-tetraoxacalix[4]arene (6). A suspension of 1 (388 mg, $0.708 \mathrm{mmol})$ and Raney-nickel in THF $(40 \mathrm{~mL})$ was stirred under $\mathrm{H}_{2}(1 \mathrm{~atm})$ at room temperature for $18 \mathrm{~h}$, then filtered on celite and washed with DMF. The filtrate was evaporated under reduced pressure, and the resulting solid was precipitated from DMF/THF and collected by suction filtration to afford 6 (234 mg, 77\% yield). M.p. $187-190{ }^{\circ} \mathrm{C}$ (dec); ${ }^{1} \mathrm{H}$ NMR $\delta 4.05$ (br s, $8 \mathrm{H}, \mathrm{NH}_{2}$ ), 5.02, 5.85, 7.09 (s, 1:1:4, 12 H, 5,18-ArH, 27,28-ArH, and 10,11,12,13,23,24,25,26ArH, respectively) ppm; ${ }^{13} \mathrm{C}$ NMR (125 MHz) $\delta$ 103.4, 103.9, 125.3, 125.5, 131.9, 136.2, 147.2 ppm. MALDI-TOF, m/z 428.1 [M] ${ }^{+}$. Anal. Calcd. for $\mathrm{C}_{24} \mathrm{H}_{20} \mathrm{~N}_{4} \mathrm{O}_{4}$ : C 67.28; H 4.71; N 13.08 . Found: C 66.95; H 4.81; N 12.94.

4,6,16,18-Tetraamino-2,8,14,20-tetraoxacalix[4]arene (7). A suspension of 2 (1.89 g, 3.45 mmol) and Raney-nickel in THF $(150 \mathrm{~mL})$ was stirred under $\mathrm{H}_{2}(1 \mathrm{~atm})$ at room temperature for $18 \mathrm{~h}$, and then filtered on celite. The solvent was evaporated under reduced pressure, and the residual solid was triturated with acetone and collected by suction filtration to afford 7 (1.13 g, 76\% yield); M.p. $287-290{ }^{\circ} \mathrm{C}$ (dec); ${ }^{1} \mathrm{H}$ NMR $\delta 4.51$ (br s, $8 \mathrm{H}, \mathrm{NH}$ ), 5.95 (t, $J=2.3 \mathrm{~Hz}, 2 \mathrm{H}$, 25,27-ArH), 6.14, 6.28 (s, 1:1, 4 H, 5,17-ArH, 26,28-ArH), 6.71 (dd, $J=2.3$, $8.2 \mathrm{~Hz}, 4 \mathrm{H}$, 10,12,22,24-ArH), 7.24 (t, $J=8.2 \mathrm{~Hz}, 2 \mathrm{H}, 11,23-\mathrm{Ar} H$ ) ppm; ${ }^{13} \mathrm{C}$ NMR $\delta$ 98.8, 102.3, 110.2, 114.8, 130.1, 130.3, 138.2, 160.3 ppm. MALDI-TOF, m/z $428.6[\mathrm{M}]^{+}$. Anal. Calcd. for $\mathrm{C}_{24} \mathrm{H}_{20} \mathrm{~N}_{4} \mathrm{O}_{4} \cdot{ }^{1} /{ }_{2} \mathrm{H}_{2} \mathrm{O}$ : C 65.90; $\mathrm{H}$ 4.84; N 12.81. Found: C 65.72; H 4.98; N 12.68.

4,6,15,17-Tetraamino-2,8,13,19-tetraoxacalix[4]arene (8). A suspension of 3 (140 mg, $0.255 \mathrm{mmol})$ and Raney-nickel in DMF $(14 \mathrm{~mL})$ was stirred under $\mathrm{H}_{2}$ (1 atm) at room temperature for $18 \mathrm{~h}$. The residual Raney-nickel catalyst was mechanically removed from the reaction mixture with a magnetic bar and the resulting suspension was evaporated. The crude solid (90 mg, 82\% yield) was used without further purification in the subsequent step. ${ }^{1} \mathrm{H}$ NMR $\delta$ 4.46 (br s, $8 \mathrm{H}, \mathrm{NH}_{2}$ ), 5.05, 6.17, 6.86 (s, 1:1:4, $12 \mathrm{H}$, 5,16-ArH, 25,28-ArH, and 10,11,21,22,23,24,26,27-ArH, respectively) ppm.

4,6,18,20-Tetraamino-2,8,16,22-tetraoxacalix[2]arene[2]naphthalene (9). A suspension of 4 (200 mg, $0.309 \mathrm{mmol}$ ) and Raney-nickel in THF (15 mL) was stirred under $\mathrm{H}_{2}(1 \mathrm{~atm})$ at room temperature for $18 \mathrm{~h}$, then filtered on celite and washed with DMF. The filtrate was evaporated under reduced pressure, and the resulting solid was precipitated from DMF/THF and collected by suction filtration to afford 9 (140 mg, 86\% yield); M.p. 298-301 ${ }^{\circ} \mathrm{C}$ (dec); ${ }^{1} \mathrm{H}$ NMR $\delta 4.59$ (br s, $8 \mathrm{H}, \mathrm{NH}_{2}$ ), 6.33, 6.51 (s, 1:1, 4 H, 5,19-ArH, 32,36-ArH), 6,80 (d, $J=2.4$ Hz, 4 H, 29,31,33,35naphth), 7.18 (dd, $J=2.4,8.9 \mathrm{~Hz}, 4 \mathrm{H}, 10,14,24,28-n a p h t h), 7.78$ (d, $J=8.9 \mathrm{~Hz}, 4 \mathrm{H}$, 11,13,25,27-naphth) ppm; ${ }^{13} \mathrm{C}$ NMR $\delta$ 102.7, 106.6, 116.4, 116.6, 124.6, 129.1, 130.3, 135.1, 138.9, 158.2 ppm. MALDI-TOF, $\mathrm{m} / \mathrm{z} 528.9[\mathrm{M}]^{+}$. Anal. Calcd. for $\mathrm{C}_{32} \mathrm{H}_{24} \mathrm{~N}_{4} \mathrm{O}_{4} \cdot{ }_{1}{ }_{2} \mathrm{H}_{2} \mathrm{O}$ : C 71.50; H 4.69; N 10.42. Found: C 71.27; H 4.76; N 10.38 .

4,6,19,21-Tetraamino-2,8,17,23-tetraoxacalix[2]arene[2]biphenyl (10). A suspension of 5 (200 mg, $0.285 \mathrm{mmol}$ ) and Raney-nickel in THF (15 mL) was stirred under $\mathrm{H}_{2}(1 \mathrm{~atm})$ at room temperature for $18 \mathrm{~h}$. The excess of Raney-nickel was mechanically removed from the reaction 
mixture with a magnetic bar and the resulting suspension was evaporated. The crude solid (115 mg) was used without further purification in the subsequent step. ${ }^{1} \mathrm{H}$ NMR $\delta 4.63$ (br s, $8 \mathrm{H}$, $\mathrm{NH}_{2}$ ), 5.64, 6.23 (s, 1:1, $4 \mathrm{H}, 5,20-\mathrm{ArH}$, and 35,40-ArH, respectively), 6.90 and 7.54 (ABq, $J=$ $8.5 \mathrm{~Hz}, 16 \mathrm{H}, 10,11,14,15,25,26,29,30,31,32,33,34,36,37,38,39-b i p h) \mathrm{ppm} ;{ }^{13} \mathrm{C}$ NMR $\delta 102.3$, 109.6, 119.5, 126.8, 133.0, 135.2, 135.4, $157.6 \mathrm{ppm}$.

4,6,17,19-Tetra- $N$-(1-octyl)ureido-2,8,15,21-tetraoxacalix[4]arene (11). A solution of 6 (110 mg, $0.257 \mathrm{mmol}$ ) and $n$-octyl isocyanate $(351 \mathrm{mg}, 2.26 \mathrm{mmol})$ in dry DMSO $(14 \mathrm{~mL})$ was stirred at room temperature under nitrogen for $18 \mathrm{~h}$. Solvent removal under reduced pressure gave a crude product which was filtered through a short-path layer of silica gel $\left(\mathrm{SiO}_{2}\right.$, toluene/ $\mathrm{CH}_{3} \mathrm{CN}$ 8:3 v/v). Precipitation of the residue from $\mathrm{CHCl}_{3} / \mathrm{CH}_{3} \mathrm{CN}$ gave a solid which was collected by suction filtration to afford 11 (60 mg, 22\% yield); M.p. $234-236{ }^{\circ} \mathrm{C}$ (dec); ${ }^{1} \mathrm{H}$ NMR $\delta 0.84\left(\mathrm{t}, J=6.7 \mathrm{~Hz}, 12 \mathrm{H}, \mathrm{CONHC}_{7} \mathrm{H}_{14} \mathrm{CH}_{3}\right), 1.16-1.48\left(\mathrm{~m}, 48 \mathrm{H}, \mathrm{CH}_{2}\right), 2.93-3.13(\mathrm{~m}, 8$ $\mathrm{H}, \mathrm{CONHCH}_{2} \mathrm{C}_{7} \mathrm{H}_{15}$ ), 5.30 (s, $2 \mathrm{H}, 27,28-\mathrm{ArH}$ ), 6.24 (t, $J=5.3 \mathrm{~Hz}, 4 \mathrm{H}, \mathrm{CONHC}_{8} \mathrm{H}_{17}$ ), 7.177.24 (m, 8 H, 10,11,12,13,23,24,25,26-ArH), 7.59 (s, 4 H, CONH), 7.83 (s, 2 H, 5,18-ArH) ppm; ${ }^{13} \mathrm{C}$ NMR $\delta$ 13.9, 22.1, 26.6, 28.8, 28.9, 29.8, 31.3, 102.7, 117.1, 122.7, 125.1, 126.5, 142.5, 145.9, 155.4 ppm. MALDI-TOF, m/z $1071.7[\mathrm{M} \cdot \mathrm{Na}]^{+}, 1087.7[\mathrm{M} \cdot \mathrm{K}]^{+}$. Anal. Calcd. for $\mathrm{C}_{60} \mathrm{H}_{88} \mathrm{~N}_{8} \mathrm{O}_{8} \cdot \mathrm{H}_{2} \mathrm{O}$ : C 67.51; H 8.50; N 10.50. Found: C 67.32; H 8.39; N 10.44.

4,6,16,18- Tetra- $N$-(1-octyl)ureido-2,8,14,20-tetraoxacalix[4]arene (12). A solution of 7 (200 mg, $0.467 \mathrm{mmol}$ ) and $n$-octyl isocyanate (957 mg, $6.16 \mathrm{mmol})$ in dry $\mathrm{CHCl}_{3}(110 \mathrm{~mL})$ was stirred at room temperature under nitrogen for 4 days. Solvent removal under reduced pressure gave a residue, which was triturated with acetone and filtered to afford 12 (179 mg, 37\% yield); M.p. $247-250{ }^{\circ} \mathrm{C}$ (dec); ${ }^{1} \mathrm{H}$ NMR $\delta 0.83$ (t, $J=6.7 \mathrm{~Hz}, 12 \mathrm{H}, \mathrm{CONHC}_{7} \mathrm{H}_{14} \mathrm{CH}_{3}$ ), 1.17-1.41 (m, $48 \mathrm{H}, \mathrm{CH}_{2}$ ), 2.96-3.04 (m, $8 \mathrm{H}, \mathrm{CONHCH}_{2} \mathrm{C}_{7} \mathrm{H}_{15}$ ), 6.03 (t, $\left.J=2.3 \mathrm{~Hz}, 2 \mathrm{H}, 25,27-\mathrm{ArH}\right), 6.32$ (s, $2 \mathrm{H}, 26,28-\mathrm{ArH}), 6.57$ (t, $J=5.5 \mathrm{~Hz}, 4 \mathrm{H}, \mathrm{CONHC}_{8} \mathrm{H}_{17}$ ), 6.91 (dd, $J=2.3,8.3 \mathrm{~Hz}, 4 \mathrm{H}$, 10,12,22,24-ArH), 7.39 (t, $J=8.3$ Hz, 2 H, 11,23-ArH), 7.79 (s, 4 H, CONH), 8.87 (s, 2 H, 5,17$\mathrm{ArH}$ ) ppm; ${ }^{13} \mathrm{C}$ NMR $\delta 13.9,22.1,26.5,28.7,28.8,29.7,31.3,103.3,109.9,112.0,113.3,128.4$, 131.0, 137.6, 154.7, 158.7 ppm. MALDI-TOF, $\mathrm{m} / \mathrm{z} 1072.9[\mathrm{M} \cdot \mathrm{Na}]^{+}, 1088.9[\mathrm{M} \cdot \mathrm{K}]^{+}$. Anal. Calcd. for $\mathrm{C}_{60} \mathrm{H}_{88} \mathrm{~N}_{8} \mathrm{O}_{8} \cdot{ }_{1}{ }_{2} \mathrm{H}_{2} \mathrm{O}$ : C 68.09; H 8.48; N 10.59. Found: C 67.94; H 8.34; N 10.56.

4,6,15,17-Tetra- $N$-(1-octyl)ureido-2,8,13,19-tetraoxacalix[4]arene (13). A suspension of 8 (80 mg of crude product from the previous step) and $n$-octyl isocyanate (287 $\mathrm{mg}, 1.85 \mathrm{mmol}$ ) in dry DMSO (15 mL) was heated to $50{ }^{\circ} \mathrm{C}$ under nitrogen for 3 days. The solvent was then removed under reduced pressure and the resulting residue was triturated with $\mathrm{CHCl}_{3}$ and collected by filtration (62 mg, 26\% yield from 3); M.p. $292-295{ }^{\circ} \mathrm{C}$ (dec); ${ }^{1} \mathrm{H}$ NMR $\delta 0.85$ (t, $J=$ $\left.6.7 \mathrm{~Hz}, 12 \mathrm{H}, \mathrm{CONHC}_{7} \mathrm{H}_{14} \mathrm{CH}_{3}\right), 1.16-1.47$ (m, $\left.48 \mathrm{H}, \mathrm{CH}_{2}\right), 3.02-3.10$ (m, $8 \mathrm{H}$, $\mathrm{CONHCH}_{2} \mathrm{C}_{7} \mathrm{H}_{15}$ ), 5.12 (s, $\left.2 \mathrm{H}, 25,28-\mathrm{ArH}\right), 6.58$ (t, $\left.J=4.9 \mathrm{~Hz}, 4 \mathrm{H}, \mathrm{CONHC}_{8} \mathrm{H}_{17}\right), 7.04$ (s, $8 \mathrm{H}$, 10,11,21,22,23,24,26,27-ArH), 7.91 (s, 4 H, CONH), 8.67 (s, 2 H, 5,16-ArH) ppm; ${ }^{13} \mathrm{C}$ NMR (125 MHz) $\delta 13.9,22.1,26.4,26.7,28.68,28.74,29.7,31.2,122.9,123.9 \times 2,143.7,151.7,155.1$ ppm. MALDI-TOF, m/z $1050.9[\mathrm{M} \cdot \mathrm{H}]^{+}, 1072.9[\mathrm{M} \cdot \mathrm{Na}]^{+}, 1088.9[\mathrm{M} \cdot \mathrm{K}]^{+}$. Anal. Calcd. for $\mathrm{C}_{60} \mathrm{H}_{88} \mathrm{~N}_{8} \mathrm{O}_{8} \cdot \mathrm{H}_{2} \mathrm{O}$ : C 67.51; H 8.50; N 10.50. Found: C 67.76; H 8.58; N 10.39. 
4,6,18,20-Tetra- $N$-(1-octyl)ureido-2,8,16,22-tetraoxacalix[2]arene[2]naphthalene (14). A solution of 9 (130 mg, $0.246 \mathrm{mmol}$ ) and n-octyl isocyanate (504 mg, $3.25 \mathrm{mmol}$ ) in dry DMSO $(15 \mathrm{~mL})$ was heated to $50{ }^{\circ} \mathrm{C}$ under nitrogen for 4 days. After being cooled to room temperature, the suspension was filtered and the filtrate was evaporated under reduced pressure. The resulting residue was dissolved in $\mathrm{CHCl}_{3}$ and precipitated twice from $\mathrm{CH}_{3} \mathrm{CN}$ to afford a pale gray powder (65 mg, 23\% yield); M.p. 237-240 ${ }^{\circ} \mathrm{C}$ (dec); ${ }^{1} \mathrm{H}$ NMR $\delta 0.83$ (t, $J=6.6 \mathrm{~Hz}, 12 \mathrm{H}$, $\mathrm{CONHC}_{7} \mathrm{H}_{14} \mathrm{CH}_{3}$ ), 1.13-1.40 (m, $48 \mathrm{H}, \mathrm{CH}_{2}$ ), 2.94-3.05 (m, $8 \mathrm{H}, \mathrm{CONHCH}_{2} \mathrm{C}_{7} \mathrm{H}_{15}$ ), 6.62 (s, 2 H, 32,36-ArH), 6.66 (t, $J=5.4 \mathrm{~Hz}, 4 \mathrm{H}, \mathrm{CONHC}_{8} \mathrm{H}_{17}$ ), 7,20 (d, $J=2.4 \mathrm{~Hz}, 4 \mathrm{H}, 29,31,33$,35napht), 7.24 (dd, $J=2.4,8.9 \mathrm{~Hz}, 4 \mathrm{H}, 10,14,24,28-n a p h t), 7.78$ (s, $4 \mathrm{H}, \mathrm{CONH}$ ), 9.14 (s, $2 \mathrm{H}$, 5,19-ArH) ppm; ${ }^{13} \mathrm{C}$ NMR (125 MHz) $\delta$ 13.9, 22.0, 26.4, 28.6, 28.7, 29.6, 31.2, 104.5, 108.4, 111.9, 114.5, 117.1, 125.1, 129.0, 130.3, 136.5, 154.7, 157.6 ppm. MALDI-TOF, m/z 1171.4 $[\mathrm{M} \cdot \mathrm{Na}]^{+}, 1187.5[\mathrm{M} \cdot \mathrm{K}]^{+}$. Anal. Calcd. for $\mathrm{C}_{68} \mathrm{H}_{92} \mathrm{~N}_{8} \mathrm{O}_{8} \cdot{ }^{1}{ }_{2} \mathrm{H}_{2} \mathrm{O}$ : C 70.50; H 8.09; N 9.67. Found: C 70.22; H 8.07; N 9.65.

4,6,19,21-Tetra- $N$-(1-octyl)ureido-2,8,17,23-tetraoxacalix[2]arene[2]biphenyl (15). A suspension of 10 (103 $\mathrm{mg}$ of crude product from the previous step) and $n$-octyl isocyanate (242 mg, $1.56 \mathrm{mmol}$ ) in dry DMSO (15 mL) was heated to $50{ }^{\circ} \mathrm{C}$ under nitrogen for $18 \mathrm{~h}$. After being cooled to room temperature, the suspension was filtered and the filtrate was evaporated under reduced pressure. The resulting residue was triturated with $\mathrm{CHCl}_{3}$ and collected by filtration (110 mg, 36\% yield from 5); M.p. 292-295 ${ }^{\circ} \mathrm{C}$ (dec); ${ }^{1} \mathrm{H}$ NMR $\delta 0.84$ (t, $J=6.8 \mathrm{~Hz}, 12$ $\mathrm{H}, \mathrm{CONHC}_{7} \mathrm{H}_{14} \mathrm{CH}_{3}$ ), 1.20-1.48 (m, $\left.48 \mathrm{H}, \mathrm{CH}_{2}\right), 3.02-3.11\left(\mathrm{~m}, 8 \mathrm{H}, \mathrm{CONHCH}_{2} \mathrm{C}_{7} \mathrm{H}_{15}\right), 5.66$ (s, $2 \mathrm{H}, 35,40-\mathrm{ArH}), 6.62$ (t, $\left.J=4.8 \mathrm{~Hz}, 4 \mathrm{H}, \mathrm{CONHC}_{8} \mathrm{H}_{17}\right), 7.01$ and $7.58(\mathrm{ABq}, J=8.6 \mathrm{~Hz}, 16 \mathrm{H}$, 10,11,14,15,25,26,29,30,31,32,33,34,36,37,38,39-biph), 7.97 (s, 4 H, CONH), 8.77 (s, 2 H, 5,20$\mathrm{ArH}$ ) ppm; ${ }^{13} \mathrm{C}$ NMR $\delta 14.0,22.1,26.4,28.7,28.8,29.8,31.3,104.9,112.8,120.9,124.7,127.3$, 134.4, 141.8, 155.1, 155.4 ppm. MALDI-TOF, $\mathrm{m} / \mathrm{z} 1201.7\left[\mathrm{M} \cdot \mathrm{H}^{+}\right], 1223.7\left[\mathrm{M} \cdot \mathrm{Na}^{+}\right], 1239.7$ [M.K ${ }^{+}$]. Anal. Calcd. for $\mathrm{C}_{72} \mathrm{H}_{96} \mathrm{~N}_{8} \mathrm{O}_{8} \cdot \mathrm{H}_{2} \mathrm{O}$ : C 70.91; H 8.10; N 9.19. Found: C 70.54; H 7:79; N 9.23.

\section{Acknowledgements}

We are grateful to MIUR (PRIN-2006 project) for financial support of this work.

\section{References}

1. (a) Böhmer, V. Angew. Chem. Int. Ed. 1995, 34, 713. (b) Ikeda, A.; Shinkai, S. Chem. Rev. 1997, 97, 1713. “(c) Gutsche, C. D. Calixarenes - An Introduction; Stoddart, J. F., Ed.; Monographs in Supramolecular Chemistry, $2^{\text {nd }}$ Ed.; The Royal Society of Chemistry: Cambridge, U.K., 2008; Vol. 6. (d) McMahon, G.; O’Malley, S.; Nolan, K. ARKIVOC 2003, (vii), 23. (e) Sliwa, W. ARKIVOC 2006, (v), 137. 
2. For reviews concerning heterocalix(hetero)arenas, see: (a) König, B.; Fonseca, M. H. Eur. J. Inorg. Chem. 2000, 2303. (b) Vysotsky, M.; Saadioui, M.; Böhmer, V. in Calixarenes 2001; Asfari, Z., Böhmer, V., Harrowfield, J., Vicens, J., Eds.; Kluwer Academic Publishers: Dordrecht, 2001; p 250. (c) Lhotak, P. Eur. J. Org. Chem. 2004, 1675. (d) Morohashi, N.; Narumi, F.; Iki, N.; Hattori, T.; Miyano, S. Chem. Rev. 2006, 106, 5291. (e) Wang, M.-X. Chem. Commun. 2008, 4541. For tetraazamacrocycles with alternating meta-para linkages, see (f) Hauck, S. I.; Lakshmi, K. V.; Hartwig, J. F. Org. Lett. 1999, 1, 2057. (g) Ito, A.; Ono, Y.; Tanaka, K. Angew. Chem., Int. Ed. 2000, 39, 1072. (h) Ito, A.; Yamagishi, Y.; Fukui, K.; Inoue, S.; Hirao, Y.; Furukawa, K.; Kato, T.; Tanaka, K. Chem. Commun. 2008, 6573.

3. For recent reviews, see: (a) Pappalardo, S.; Parisi, M. F. In Comprehensive Heterocyclic Chemistry III, Katritzky, A. R., Ramsden, C. A., Scriven, E. F. V., Taylor, R. J. K., Eds.; Elsevier: Oxford, 2008; Vol. 14, p 667. (b) Dehaen, W.; Maes, W. Chem. Soc. Rev. 2008, 37, 2393.

4. Sommer, N.; Staab, H. A. Tetrahedron Lett. 1966, 25, 2837.

5. Lehmann, F. P. A. Tetrahedron 1974, 30, 727.

6. Gilbert, E. E. J. Heterocyclic Chem. 1974, 11, 899.

7. Boros, E. F.; Andrews C. W.; Davis, A. O. J. Org. Chem. 1996, 61, 2553.

8. Abd-El-Aziz, A. S.; de Denus, C. R.; Zaworotko M. J.; Sharma, C. V. Chem. Commun. 1998, 265.

9. Bottino, F.; Foti, S.; Pappalardo, S. Tetrahedron 1976, 32, 2567.

10. Katz, J. L.; Feldman, M. B.; Conry, R. R. Org. Lett. 2005, 7, 91.

11. For a recent review on dynamic covalent chemistry, see: Rowan, S. J.; Cantrill, S. J.; Cousins, G. R. L.; Sanders, J. K. M.; Stoddart, J. F. Angew. Chem., Int. Ed. 2002, 41, 898.

12. Hao, E.; Fronczek, F. R.; Vicente, M. H. J. Org. Chem. 2006, 71, 1233.

13. Csokai, V.; Kulik, B.; Bitter, I. Supramol. Chem. 2006, 18, 111.

14. (a) Chambers, R. D.; Hoskin, P. R.; Khalil, A.; Richmond, P.; Sandford, G.; Yufit, D. S.; Howard, J. A. K. J. Fluorine Chem. 2002, 116, 19. (b) Chambers, R. D.; Hoskin, P. R.; Kenwright, A. R.; Khalil, A.; Richmond, P.; Sandford, G.; Yufit D. S.; Howard, J. A. K. Org. Biomol. Chem. 2003, 1, 2137. (c) Katz, J. L.; Geller B. J.; Conry, R. R. Org. Lett. 2006, 8, 2755.

15. Maes, W.; Van Rossom, W.; Van Hecke, K.; Van Meervelt L.; Dehaen, W. Org. Lett. 2006, 8, 4161.

16. (a) Wang M.-X.; Yang, H.-B. J. Am. Chem. Soc. 2004, 126, 15412. (b) Hou, B.-Y.; Zheng, Q.-Y.; Wang, D.-X.; Huang, Z.-T.; Wang, M.-X. Chem. Commun. 2008, 3864.

17. Katz, J. L.; Geller, B. J.; Foster, P. D. Chem. Commun. 2007, 1026.

18. Yang, F.; Yan, L.; Ma, K.; Yang, L.; Li, J.; Chen, L.; You, J. Eur. J. Org. Chem. 2006, 1109.

19. For leading references on the complexing abilities of anion receptors adorned with ureido functions, see: (a) Schmidtchen, F. P.; Berger, M. Chem. Rev. 1997, 97, 1609. (b) Choi, K.; Hamilton, A. D. Coord. Chem. Rev. 2003, 240, 101. (c) Gale, P. A. Coord. Chem. Rev. 2003, 240, 191. (d) Hay, B. P.; Firman, T. K.; Moyer, B. A. J. Am. Chem. Soc. 2005, 127, 1810. 
20. (a) Ballistreri, F. P.; Notti, A.; Pappalardo, S.; Parisi, M. F.; Pisagatti, I. Org. Lett. 2003, 5, 1072. (b) Garozzo, D.; Gattuso, G.; Notti, A.; Pappalardo, A.; Pappalardo, S.; Parisi, M. F.; Perez, M.; Pisagatti, I. Angew. Chem., Int. Ed. 2005, 45, 4892.

21. For tetranitro-thiacalix[4]arene analogues, see Montaudo, G.; Bottino, F.; Trivellone, E. J. Org. Chem. 1972, 37, 504.

22. With the exception of 3, whose intra-annular hydrogen atoms resonate at $\delta=7.56 \mathrm{ppm}$.

23. Hehre, W. J.; Radom, L.; Schleyer, P. R.; Pople, J. A. Ab Initio Molecular Orbital Theory; Wiley: New York, 1985. Calculations performed with Spartan'06, Wavefunction, Inc.: Irvine, CA, 2006; http://www.wavefun.com/.

24. Perrin, D. D.; Armarego, W. L. F. Purification of Laboratory Chemicals; Pergamon Press: Oxford, 1989. 